(C) 2014

Рыжкова Т. Н., кандидат технических наук, Гончарова И. И., кандидат сельскохозяйственных наук, Гейда И. Н., ассистент

Харьковская государственная зооветеринарная академия

\title{
ЭФФЕКТИВНОСТЬ ПЕРЕРАБОТКИ МОЛОЧНОГО СЫРЬЯ НА АССОРТИМЕНТ МОЛОЧНОЙ ПРОДУКЦИИ В ЗАВИСИМОСТИ ОТ ПОРОДЫ
}

\author{
Рецензент - доктор сельскохозяйственных наук, профессор Ю. Д. Рубан
}

В статье приводятся сравнительные данные результатов исследований состава проб молока от двух групп украинской черно-пёстрой и украинской красно-пёстрой молочных пород коров, содержащихся в учебно-научном иентре Харьковской государственной зооветеринарной академии для выбора оптимальной технологической схемы его переработки на готовые молочные продукты. Установлено, что молоко от украинской красно-пёстрой молочной породы коров иелесообразно перерабатывать на сычужные сыры, а от украинской черно-пестрой породы необходимо направлять на изготовление иельномолочной продукиии.

Ключевые слова: молоко, порода, физикохимический, биохимический состав, технологическая схема переработки.

Актуальность проблемы. Современная промышленная переработка молока, основанная на высокотехнологических процессах, предъявляет повышенные требования к качеству молока, используемого в качестве сырья для производства широкого ассортимента молочных продуктов. Поэтому одним из главных приоритетных направлений молочного скотоводства является производство молока, соответствующего санитарно-гигиеническим нормам и требованиям перерабатывающих предприятий.

В качестве критерия при расчетах на закупаемое молоко предприятия-переработчики используют такие показатели, как содержание жира и белка в молоке, температура охлажденного молока, кислотность, плотность, точка замерзания, бактериальная обсемененность, число соматических клеток и другие.

Сложность решения проблемы качества молока связана с тем, что применяемые в большинстве молочных хозяйств Украины технологии и санитарно-производственная культура не совместимы с условиями получения качественного и безопасного молока, а это требует пересмотра технологий производства сырого молока и профилактических мероприятий, направленных на повышение его качества $[1,3]$.
Существенной проблемой молочного скотоводства остается сезонность производства молока. В отдельные сезоны года поставки молока оптимального качества довольно не стабильны, что создает технологам существенные проблемы по производству запланированного количества молочных продуктов и вынуждает периодически перестраивать режимы своей работы с неизбежным снижением ее эффективности и рентабельности.

В связи с тем, что производители молока поставлены в жесткие условия рынка, возникает необходимость улучшения качества получаемого молока. Одним из важнейших элементов этой работы является организация производственного контроля качества молока-сырья на животноводческих фермах и централизованная система оценки качества молока в испытательных лабораториях.

Анализ последних исследований и публикаций по данной проблеме. Наряду с организацией производственного контроля, производителям молока важно управлять качеством получаемого молока, для чего необходимо знать, какие именно факторы влияют на его показатели.

Это позволит разработать оптимальные параметры технологических процессов, выполнение которых обеспечит получение молока гарантированного качества и повышение рентабельности его производства при переработке молока на питьевое молоко и молочные продукты [2, 3].

В числе таких факторов - сезонные изменения технологических процессов (кормление, способы содержания, климатические условия).

Известно, что к основным технологическим свойствам молока относят термоустойчивость и сычужную свертываемость. Молоко, полученное от здоровых животных, обладает термоустойчивостью (термостабильностью), т.е. способностью при высоких температурах сохранять первоначальные свойства. Оно обладает стойкостью при нагревании до $100{ }^{\circ} \mathrm{C}$ в течение нескольких десятков минут. При более высоких температурах 


\section{СІЛЬСЬКЕ ГОСПОДАРСТВО. ТВАРИННИЦТВО}

и продолжительной выдержке его белки могут коагулировать. Продолжительность нагревания при $130{ }^{\circ} \mathrm{C}$ до коагуляции белков в различных образцах молока колеблется от 2 до 60 мин и выше.

Основными причинами низкой термоустойчивости молока являются повышенная кислотность и нарушенный солевой и белковый состав.

Колебания состава молока зависят от времени года, стадии лактации, болезней, породы, индивидуальных особенностей животных, рационов кормления.

Термоустойчивость молока необходимо контролировать при производстве стерилизованного молока, молочных консервов, продуктов детского питания.

Под сычужной свертываемостью молока понимают способность его белков коагулировать под действием внесенного сычужного фермента с образованием относительно плотного сгустка. Так, при стандартных условиях проведения сычужной пробы продолжительность свертывания может составлять 10-35 минут. Иногда молоко очень медленно свертывается под действием сычужного фермента или вовсе не свертывается. Такое молоко называют сычужно-вялым [3].

Технологические свойства молока различных пород скота неодинаковы. Например, молоко коров симментальской, костромской, швицкой пород содержит больше кальция и быстрее свертывается сычужным ферментом, чем молоко коров украинской черно-пестрой и красной степной молочных пород, которое характеризуется мелкими мицеллами казеина и высокой термоустойчивостью.

Жировые шарики крупнее в молоке коров красной горбатовской, ярославской пород, и мельче в молоке коров украинской красной степной и черно-пестрой молочных пород [1-4].

Целью наших исследований является изучение физико-химического и биохимического сос- тава среднесуточных проб молочного сырья, полученного в течение трех суток от групп двух (черно-пёстрой и красно-пёстрой украинской молочных пород) коров, находящихся в учебнонаучном центре Харьковской государственной зооветеринарной академии, для определения эффективности использования того или иного молока при переработке на цельномолочную продукцию, продукты для детского питания или на ферментированные молочные продукты (сычужные сыры).

Методика исследований. Содержание влаги в процентах определяли по ГОСТ 1340096-3-92; массовую долю жира и белка в процентах - по ISO 9001:2000 инструментально на приборе «Bentley-150»; подсчет соматических клеток на приборе комбинированной модели Somacount 150 и «Bentley-150» (Сертификат IDA 0001461-1 от 16.12.2004 SCC); аминокислоты в мг/100 мг по ISO 13903: 2005 «Составляющие кормов для животных.

Определение содержания аминокислот; жирные кислоты, в мг/100 мг - по ГОСТ 3418-96 «Методы определения жирнокислотного состава» на газожидкостном хроматографе «Хром-5».

Результаты исследований. Физико-химические показатели молока от двух пород коров представлены в табл. 1 .

Из данных табл. 1 видно, что массовая доля влаги в среднесуточных пробах украинской черно-пёстрой молочной и украинской краснопёстрой молочной породы коров была практически одинаковой.

Массовая доля жира в молоке украинской красно-пёстрой превышала аналогичные показатели молока коров украинской черно-пёстрой молочной на $0,2 \%(\mathrm{P} \geq 0,95)$.

Достоверной разницы между показателями массовой долей жира и титруемой кислотности в молоке двух пород коров не установлено $(\mathrm{P} \leq 0,90)$.

\section{1. Физико-химические показатели молока двух пород}

\begin{tabular}{|c|c|c|}
\hline Показатели & $\begin{array}{c}\text { Украинская черно-пёстрая } \\
\text { молочная порода }\end{array}$ & $\begin{array}{c}\text { Украинская красно-пёстрая } \\
\text { молочная порода }\end{array}$ \\
\hline Массовая доля влаги, \% & $88,90 \pm 0,05$ & $88,65 \pm 0,05$ \\
\hline Массовая доля сухих веществ & $11,10 \pm 0,1$ & $11,35 \pm 0,05$ \\
\hline Массовая доля жира \% & $3,88 \pm 0,05$ & $4,08 \pm 0,05$ \\
\hline Массовая доля белка, \% & $2,57 \pm 0,05$ & $2,78 \pm 0,05$ \\
\hline Кислотность, ${ }^{\circ}$ T & $18,0 \pm 0,05$ & $211 \pm 0,05$ \\
\hline $\begin{array}{c}\text { Количество соматических } \\
\text { клеток, тыс. в 1 см }\end{array}$ & $393 \pm 0,05$ & 205 \\
\hline
\end{tabular}


СІЛЬСЬКЕ ГОСПОДАРСТВО. ТВАРИННИЦТВО

\section{2. Аминокислотный состав молока двух пород коров, мг/100 мг молока}

\begin{tabular}{|c|c|c|}
\hline Наименование аминокислот & $\begin{array}{c}\text { Украинская черно-пёстрая } \\
\text { молочная порода }\end{array}$ & $\begin{array}{c}\text { Украинская красно-пёстрая } \\
\text { молочная порода }\end{array}$ \\
\hline Аспарагиновая & $0,10 \pm 0,05$ & $0,12 \pm 0,05$ \\
\hline Треонин & $0,12 \pm 0,05$ & $0,14 \pm 0,05$ \\
\hline Серин & $0,13 \pm 0,05$ & $0,15 \pm 0,05$ \\
\hline Глутаминовая & $0,37 \pm 0,05$ & $0,39 \pm 0,05$ \\
\hline Пролин & $0,17 \pm 0,05$ & $0,17 \pm 0,05$ \\
\hline Цистин + Глицин & $0,07 \pm 0,005$ & $0,07 \pm 0,005$ \\
\hline Аланин & $0,09 \pm 0,05$ & $0,09 \pm 0,05$ \\
\hline Валин & $0,18 \pm 0,05$ & $0,18 \pm 0,05$ \\
\hline Метионин & $0,07 \pm 0,005$ & $0,07 \pm 0,005$ \\
\hline Изолейцин & $0,13 \pm 0,05$ & $0,14 \pm 0,05$ \\
\hline Лейцин & $0,21 \pm 0,05$ & $0,25 \pm 0,05$ \\
\hline Тирозин & $0,12 \pm 0,05$ & $0,13 \pm 0,005$ \\
\hline Фенилаланин & $0,18 \pm 0,05$ & $0,20 \pm 0,005$ \\
\hline Гистидин & $0,09 \pm 0,005$ & $0,09 \pm 0,005$ \\
\hline Лизин & $0,19 \pm 0,05$ & $0,22 \pm 0,05$ \\
\hline Аргинин & $0,10 \pm 0,05$ & $0,13 \pm 0,05$ \\
\hline Сумма незаменимых & $1,27 \pm 0,05$ & $1,42 \pm 0,05$ \\
\hline аминокислот & & \\
\hline
\end{tabular}

3. Жирно-кислотный состав проб.молока от двух видов жсивотных, мг/100 мг молока

\begin{tabular}{|c|c|c|}
\hline Наименование жирных кислот & $\begin{array}{c}\text { Украинская черно-пёстрая } \\
\text { молочная порода }\end{array}$ & $\begin{array}{c}\text { Украинская красно-пёстрая } \\
\text { молочная порода }\end{array}$ \\
\hline Масляная $\left(\mathrm{C}_{4: 0}\right)$ & $0,11 \pm 0,05$ & $0,10 \pm 0,05$ \\
\hline Капроновая $\left(\mathrm{C}_{6: 0}\right)$ & $0,08 \pm 0,005$ & $0,07 \pm 0,005$ \\
\hline Каприловая $\left(\mathrm{C}_{8: 0}\right)$ & $0,04 \pm 0,005$ & $0,04 \pm 0,005$ \\
\hline Каприновая $\left(\mathrm{C}_{10: 0}\right)$ & $0,09 \pm 0,005$ & $0,09 \pm 0,005$ \\
\hline Лауриновая $\left(\mathrm{C}_{12: 0}\right)$ & $0,10 \pm 0,05$ & $0,11 \pm 0,05$ \\
\hline Миристиновая $\left(\mathrm{C}_{14: 0}\right)$ & $0,45 \pm 0,05$ & $0,47 \pm 0,05$ \\
\hline Миристолеиновая $\left(\mathrm{C}_{14: 1}\right)$ & $0,05 \pm 0,005$ & $0,05 \pm 0,005$ \\
\hline Пальмитиновая $\left(\mathrm{C}_{16: 0}\right)$ & $0,64 \pm 0,05$ & $0,63 \pm 0,05$ \\
\hline Пальмитолеиновая $\left(\mathrm{C}_{16: 1}\right)$ & $0,09 \pm 0,005$ & $0,08 \pm 0,005$ \\
\hline Маргариновая $\left(\mathrm{C}_{17: 0}\right)$ & $0,02 \pm 0,005$ & $0,02 \pm 0,005$ \\
\hline Стеариновая $\left(\mathrm{C}_{18: 0}\right)$ & $0,35 \pm 0,05$ & $0,32 \pm 0,05$ \\
\hline Олеиновая $\left(\mathrm{C}_{18: 1}\right)$ & $0,68 \pm 0,05$ & $0,65 \pm 0,05$ \\
\hline Линолевая $\left(\mathrm{C}_{18: 2}\right)$ & $0,09 \pm 0,005$ & $0,09 \pm 0,005$ \\
\hline Линоленовая $\left(\mathrm{C}_{18: 3}\right)$ & $0,03 \pm 0,005$ & $0,03 \pm 0,005$ \\
\hline Арахиновая $\left(\mathrm{C}_{20: 0}\right)$ & $0,04 \pm 0,005$ & $0,04 \pm 0,005$ \\
\hline Арахидоновая $\left(\mathrm{C}_{20: 4}\right)$ & $0,09 \pm 0,005$ & $0,09 \pm 0,005$ \\
\hline Сумма незаменимых & $0,25 \pm 0,05$ & $0,25 \pm 0,05$ \\
\hline жирных кислот & $0,42 \pm 0,05$ & $0,41 \pm 0,05$ \\
\hline $\begin{array}{c}\text { Сумма низкомолекулярных } \\
\text { жирных кислот }\end{array}$ & & \\
\hline
\end{tabular}

Титруемая кислотность молока свидетельствует о его высокой степени хранимоспособности $(\mathrm{P} \geq 0,90)$.

Массовая доля белка молока от коров украинской красно-пёстрой породы коров была боль- шей, в сравнении с аналогичным показателем молока от коров украинской черно-пёстрой молочной породы коров на $0,21 \%(\mathrm{P} \leq 0,90)$.

В молоке украинской красно-пёстрой породы количество соматических клеток было меньшим, 


\section{СІЛЬСЬКЕ ГОСПОДАРСТВО. ТВАРИННИЦТВО}

чем в молоке украинской черно- пёстрой молочной породы коров, соответственно, в 2 раза $(\mathrm{P} \leq 0,90)$.

Это свидетельствует о высокой степени безопасности молока красно-пёстрой породы и о целесообразности его направления для изготовления продуктов для детского питания.

Исследовали аминокислотный состав молока, полученного от двух пород коров.

Результаты исследования аминокислотного состава молока от двух пород коров представлены в табл. 2.

Достоверной разницы между показателями незаменимых аминокислот в молоке двух пород не установлено $(\mathrm{P} \leq 0,95)$. Жирно-кислотный состав молока от двух видов животных представлен в табл. 3. Из данных табл. 3 видно, что достоверной разницы между показателями незаменимых жирных кислот в молоке от коров двух пород не установлено $(\mathrm{P} \leq 0,95)$.

\section{БИБЛИОГРАФИЯ}

1. Барабанщикков Н. В. Содержание белков в молоке коров различных пород и их свойства // Доклады ТСХА. Зоотехния. - 1971. - №167. C. 90-93.

2. Барабанщиков Н., Харитонова И., Комаров Н. Влияние породы на продуктивность и качество молока // Молочное и мясное скотоводство. - 1990. №5. - C. 41-44.

3. Барабаш А. Ф., Орлова А. В., Бычкова М. В.
Выводы: 1. На физико-химический состав молока, его технологические свойства, такие как сыропригодность и термоустойчивость, влияет порода животных.

2. При выборе технологической схемы переработки молока необходимо учитывать породу животных, условия содержания и их кормления.

3. Согласно нормативным документам, максимальная продуктивность, а также полученные нами результаты исследований амино- и жирнокислотного состава вышеуказанных двух пород коров свидетельствует о целесообразности использования молока от украинской красно-пестрой молочной породы для его использования в сыроделии, а украинской черно-пестрой молочной породы - для выработки цельномолочной продукции (питьевого молока, кисломолочных продуктов и творога).

Характеристика качества молока коров чернопестрой и красной степной пород в условиях Юга Украины // Совершенствование продуктивности и племенных качеств животных Юга Украины. - 1988. - С. 33-39.

4. Барышев А. А., Смирнов В. А., Гришин А. М. Изменение состава молока высокопродуктивных коров с возрастом // Зоотехния. - 1991. - № 2. C. 17-18. 